\title{
Sustainable Consumption: Scope and Applicability of Principles of International Law
}

\author{
Ipshita CHATURVEDI \\ Partner, C\&C Advisors, Mumbai, India \\ ipshitachaturvedi@candcadvisors.in
}

\begin{abstract}
The role of sustainable development has been increasingly recognized in international environmental law as a way to reconcile poverty eradication and resource exploitation with environmental protection. By contrast, little attention has been given to the concept of sustainable consumption. When international law mentions sustainable consumption, consumption and production are generally considered together, for instance in Goal 12 of the Sustainable Development Goals, addressing responsible consumption and production, and in UNEP's 10-year sustainable 'consumption and production programme.' While some research on sustainable consumption has been conducted in sociology and anthropology, the focus in international environmental law has remained on production rather than consumption. This article seeks to open up a discussion on how consumption should be viewed and defined legally, and the role that law could play in promoting sustainable consumption.
\end{abstract}

\section{Keywords}

sustainable development goals - sustainable consumption - consumption and production - international environmental law - role of law

* The author acknowledges the research assistance by Ms Yogini OKE, at the National University of Juridical Sciences, Kolkata, India and thanks her for her sincerity. An earlier draft of this article was presented at the Early Career Scholars Workshop in Environmental Law conducted by the Chinese University of Hong Kong (in collaboration with the Research Institute of Environmental Law, Wuhan University) on 29 April 2017. The author would also like to thank the workshop organisers and participants for their comments.

(C) IPSHITA CHATURVEDI, 2018 | DOI:10.1163/24686042-12340020

This is an open access article distributed under the terms of the prevailing CC-BY-NC license at the time of publication. 
The concept of 'sustainable development' ('SD') owes its origins to studies, often led by developed-country scientists, which suggested that the existing model of development was unsustainable because the increase in human population and the current extraction, production, consumption and pollution patterns may result into humanity exceeding the Earth's carrying capacity. ${ }^{1}$ This put the spotlight of the sustainability discourse on the developing world by directly linking the unsustainability of the development model with population growth. ${ }^{2}$ In response, developing countries pointed out that a significant share of the production needs of the West were outsourced and therefore, the blame for environmental degradation could not rest upon developing countries alone. ${ }^{3}$ They further stated that the 'development' of States in the Global South through exploitation of resources (sustainable or otherwise) could not be prevented, as developed countries themselves had been guilty of relying on such exploitation to achieve their levels of development. ${ }^{4}$ It can be said that the global concept of SD started to develop as a response to this deadlock between developed and developing countries 5 - as a way to suggest that the position of developed and developing States were not necessarily irreconcilable.

The most commonly quoted definition of SD was proposed by the Brundtland Report on 'Our Common Future': ${ }^{6}$ development 'meets the needs of the present without compromising the ability of future generations to meet their own needs. ${ }^{7}$ As Marie-Claire CORDONIER SEGGER has observed, SD is not merely a 'compromise term' for more environmentally sound ways of exploiting natural resources, but overall, a way to formulate and implement a 'new kind of development.' By focusing on development, the concept of SD suggested a focus on production and the need for production to rely on the sustainable exploitation of natural resources. Since the 1970s, an emerging body

1 Marie-Claire CORDONIER SEGGER, 'Sustainable Development in International Law' in Hans Christian BUGGE and Christina VOIGT (eds), Sustainable Development in International and National Law (Europa Law 2008) 86.

2 KR NAYAR, Politics of 'Sustainable Development' 29(22) Economic and Political Weekly 1327-1329 (1994) 1327 .

3 Ibid.

4 CORDONIER SEGGER (n 1$)$.

5 Ibid 87.

6 Report of the World Commission on Environment and Development: Our Common Future (WCED) <http://www.un-documents.net/our-common-future.pdf> 42, accessed 24 May 2018.

7 Ibid para 1.

8 CORDONIER SEGGER (n 1$) 97$. 
of legal principles and treaties has emerged in relation to the principle of SD, seeking to reconcile environmental and economic norms and regimes. Their integrated social, economic, and environmental purposes are often focused on development of a resource or resolution of a development challenge. ${ }^{9}$

These negotiations and the relevant literature, however, have given very little attention to what lies behind and drives production. As a rare exception, James SALZMAN observed: 'concentrating on laws on the reduction of waste from pipes and smokestacks, we have neglected to address the reason we produce the waste in the first place. ${ }^{10}$ In this context, sustainable consumption ('SC') relates to reducing the consumption of material goods that are resourceintensive and damaging to the environment.

Agenda 21's chapter IV dealt with changing consumption patterns ${ }^{11}$ and called for 'special attention to be paid to the demand for natural resources generated by unsustainable consumption and to the efficient use of those resources consistent with the goal of minimizing depletion. ${ }^{12}$ Apart from coining the terminology of 'sustainable consumption,' the link between resource depletion and consumption was expressly stated in a widely accepted international document for the first time, namely Agenda 21. Chapter IV further acknowledged that excessive demands and unsustainable lifestyles among the wealthier segments of societies place immense stress on the environment. ${ }^{13}$ That the poorer segments of societies are unable to meet basic human needs highlights the need to put the responsibility of lowering consumption and improving consumption patterns on developed countries. In so doing, Agenda 21 provided a potentially far-reaching mandate for examining, questioning and revising consumption patterns - and, by implication, consumer behaviours, choices, expectations and lifestyles. ${ }^{14}$

This part of Agenda 21, however, has not led to continued international cooperation to promote a sustainable model of consumption. Two decades later, the Paris Agreement only contains a fleeting allusion to sustainable consumption in its Preamble:

$9 \quad$ Ibid.

10 James SALZMAN, 'Sustainable Consumption and the Law' (1997) 27 Environmental Law 1243,1245 .

11 Agenda 21 (14 June 1992) A/CONF.151/26 vol. II was the main policy document to emerge from the United Nations Conference on Environment and Development (the Earth Summit) held in Rio de Janeiro in 1992.

12 Ibid para 3.

13 Ibid para $4 \cdot 3$.

14 SALZMAN (n 10) 1255. 
Also recognizing that sustainable lifestyles and sustainable patterns of consumption and production, with developed country Parties taking the lead, play an important role in addressing climate change, as provided for in the Convention. ${ }^{15}$

SD has acquired a legal form that enables its interpretation to be used in environmental protection globally as well as nationally. For example, SD can be said to be a positive norm under international law due to its formulation in treaties such as the Marrakesh Agreement, ${ }^{16}$ UNCLOS, ${ }^{17}$ the Convention on Biological Diversity ${ }^{18}$ and a number of Free Trade Agreements, ${ }^{19}$ among others. SD has been discussed as a principle of international environmental law by the International Court of Justice in Gabčikovo-Nagymaros ${ }^{20}$ and by Judge Bhandari in a separate opinion in Nicaragua $v$ Costa Rica ${ }^{21}$ as well as by various national and regional courts, even though the specific implications of this principle remain relatively ill-understood. ${ }^{22} \mathrm{SD}$ is one of the six principles that EU policy must follow, in the application of the Treaty on the Functioning of the European Union. ${ }^{23}$ The adoption of the Sustainable Development Goals

15 Paris Agreement, Preamble (12 December 2015) FCCC/CP/2015/L.9/Rev.1.

16 Marrakesh Agreement Establishing the World Trade Organization (15 April 1994) 1867 UNTS 154 Preamble.

17 United Nations Convention on the Law of the Sea (1o December 1982) 1833 UNTS 31363.

18 Convention on Biological Diversity (5 June 1992) 1760 UNTS 79.

19 European Commission, 'Sustainable Development' <http://ec.europa.eu/trade/policy/ policy-making/sustainable-development/> accessed 13 November 2017, noting that 'EU law requires all relevant EU policies, including trade policy, to promote sustainable development.' Gabčikovo-Nagymaros Project (Hungary v Slovakia), Judgment, ICJ Reports 1997, p 7, para 140.

21 Separate Opinion of Judge Bhandari in Certain Activities Carried Out by Nicaragua in the Border Area (Costa Rica $v$ Nicaragua) and Construction of a Road in Costa Rica along the San Juan River (Nicaragua v Costa Rica), Judgment, ICJ Reports 2015, p. 665, paras 11-13.

22 Virginie BARRAL, 'Sustainable Development in International Law: Nature and Operation of an Evolutive Legal Norm' (2017) 23(2) European Journal of International Law 377, 400.

23 Consolidated version of the Treaty on the Functioning of the European Union, 13 December 2007, 2008/C 115/01, art 11 'Environmental protection requirements must be integrated into the definition and implementation of the Union's policies and activities, in particular with a view to promoting sustainable development'; art 12 'Consumer protection requirements shall be taken into account in defining and implementing other Union policies and activities.' See also Eloise SCOTFORD, Environmental Principles and the Evolution of Environmental Law (Hart 2017) 84. 
('SDGs' $)^{24}$ reflects a global consensus on the importance of SD in guiding global policy-making.

Yet, this recognition of SD has inevitably put great emphasis on (economic) 'development' by depicting developing States as primarily States which ought to develop. As a globally recognized principle, SD helps maintain this status quo by focusing on the sustainable management of resources that are being depleted because of production. Over time, the modalities of development have been discussed extensively through SD, but not the quest for more consumption. Consequently, the fundamental question regarding the limits to individual and, by extension, societal consumption has been largely ignored.

\section{2 \\ The Development of Sustainable Consumption in International Law: A Brief History}

CORDONIER SEGGER points out that in the 19th century, MALTHUS and RICARDO implied that environmental protection measures focusing solely on pollution will not be enough if the reasons we pollute are not focused upon. ${ }^{25}$ This idea was couched in the vocabulary of population growth exceeding the Earth's carrying capacity, which was a growing concern at that time. This approach of the growth of population and individual consumption as one of the fundamental causes of environmental harm was further pursued in the 1970s. For instance, Principle 16 of the Stockholm Declaration on the Human Environment called for demographic policies as one tool to reduce the impacts of societies on the environment. ${ }^{26}$

Likewise, the Brundtland Report shed light on the inequities between the consumption levels of the developed and the developing countries. While it did not define SC as such, the Brundtland Commission clearly saw promotion

24 The 17 Sustainable Development Goals are contained in UN General Assembly resolution 70/1, 'Transforming our world: the 2030 Agenda for Sustainable Development' (25 September 2015) <http://www.un.org/ga/search/view_doc.asp?symbol=A/RES/ 70/1\&Lang=E $>$ accessed 24 May 2018.

25 See CORDONIER SEGGER (n 1 ) 93.

26 Declaration of the United Nations Conference on the Human Environment 1972 ('Stockholm Declaration'), 11 ILM 1416 (1972) Principle 16: 'Demographic policies which are without prejudice to basic human rights and which are deemed appropriate by Governments concerned should be applied in those regions where the rate of population growth or excessive population concentrations are likely to have adverse effects on the environment of the human environment and impede development.' 
of SC as an essential component of SD. ${ }^{27}$ Yet, the Earth Summit of $1992^{28}$ marked a sharp turn towards a development focus in international environmental law. From then on, environmental protection was seen as a modality of development and SD was essentially viewed as a way to ensure that natural resources could be exploited sustainably. To take the development-based narrative ahead by combining production and consumption, Principle 8 of the Rio Declaration on Environment and Development ${ }^{29}$ ('Rio Declaration') stated:

To achieve sustainable development and a higher quality of life for all people, States should reduce and eliminate unsustainable patterns of production and consumption and promote appropriate demographic policies. $^{30}$

This principle combined demographic, environmental and developmental concerns, as it called for reduction and elimination of unsustainable patterns of production and consumption. The Rio Declaration, in effect, recognized the global long-term need to consume less, or consume better, or both, ${ }^{31}$ but it laid the foundation for defining SC as a combination of both production and consumption under the overarching umbrella of 'sustainability'. In addition, Agenda 21 defined an extensive global action plan on specific environmental and development issues. Therefore, Chapter IV of Agenda 21 remains the most important policy document linking unsustainability with unchecked consumption and the need (especially for the West) to change current consumption patterns which are resource-and energy-intensive. ${ }^{32}$ However, sustainable consumption, unlike several principles of the Rio Declaration, translated into neither an international norm nor a legal concept, nor provided a basis to expand customary laws in this field, either through state practice

27 WCED (n 6), 42:

Living standards that go beyond the basic minimum are sustainable only if consumption standards everywhere have regard for long-term sustainability. Yet many of us live beyond the world's ecological means, for instance in our patterns of energy use. Perceived needs are socially and culturally determined, and sustainable development requires the promotion of values that encourage consumption standards that are within the bounds of the ecological possible and to which all can reasonably aspire.

The United Nations Conference of Environment and Development, also known as the Earth Summit, was held in Rio de Janeiro in 1992 with more than 170 participating governments.

Rio Declaration on Environment and Development (1992) A/CONF.151/26, vol. I. Ibid principle 8.

SALZMAN (n 10) 1246.

Agenda 21 (n 11) para 4.8. 
or opinio juris. No provision on consumption was found in the three treaties ${ }^{33}$ adopted at or shortly after the Earth Summit.

The year 1992 was also marked by the creation of the UN Commission for Sustainable Development (UNCSD) by the General Assembly. ${ }^{34}$ The UNCSD was to supervise the implementation of Agenda 21. From its first session in 1993 onwards, however, the UNCSD put an increasing emphasis on poverty eradication and SD, with less attention to other provisions of Agenda 21-including the content of Chapter IV. In 2013, the UNCSD was replaced by a highlevel political forum on SD, which is now a central platform for follow-up and review of the 2030 Agenda for Sustainable Development and the Sustainable Development Goals. Under the umbrella of SD, Goal 12 and its Targets are directed to ensuring sustainable consumption and production patterns (see further below).

Rewinding to 1997, a significant summit (with respect to SC) was held to review and appraise the implementation of Agenda 21. ${ }^{35}$ At this juncture, States had started viewing sustainable development as a podium supported by three interdependent pillars-economic development, social development and environmental protection-instead of SD's previous focus on bridging environmental protection and economic development. This attitude was reflected in the resulting declaration 'Programme for the Further Implementation of Agenda 21' ('Programme') which was adopted by the UnGA. ${ }^{36}$ The Programme highlighted the importance of countries undertaking programmes eliminating unsustainable consumption patterns and suggested measures such as the promotion of Sustainable Consumption and Production ('SCP') through the imposition of taxes by governments and voluntary publication of environmental and social impact assessments by businesses, among others. The Programme suggested that national policies and strategies promoting SCP should be based on the principles of Common but Differentiated Responsibilities ${ }^{37}$ and Polluter Pays. ${ }^{38}$

33 Convention on Biological Diversity (n 18), Framework Convention on Climate Change 31 ILM 849 (1992); Convention to Combat Desertification in those Countries Experiencing Serious Drought and/or Desertification, Particularly in Africa 33 ILM 1328 (1994).

34 Commission on Sustainable Development <https://sustainabledevelopment.un.org/csd .html> accessed 4 November 2017.

35 Special Session of the General Assembly to Review and Appraise the Implementation of Agenda $211992<$ https://sustainabledevelopment.un.org/milestones/gass19> accessed 9 January 2017.

36 UN General Assembly resolution 19/2, 'Programme for the Further Implementation of Agenda 21' (19 September 1997) para 23.

37 Ibid paras 22, 26, 28, and 33 .

$38 \quad$ Ibid paras 14 and 28. 
The Johannesburg World Summit on Sustainable Development ${ }^{39}$ in 2002 focused on the implementation of SD in a globalized world in light of renewed commitments of the developed world to provide technological and financial assistance to developing countries. This set the study of international environmental law further in the context of sustainable production and related economic, administrative and political challenges for implementation of sustainable production in the third world. Annexed to the resolutions undertaken at the summit was a 'Plan of Implementation' ${ }^{40}$ which addressed SCP by calling for a 10-year framework in support of regional and national initiatives to accelerate the shift towards SCP, discussed further below.

The concept of SC again came to the fore a decade later, in the outcome document of the UN Conference on Sustainable Development ('Rio+2o'). This outcome document identified the promotion of SCP patterns as a characteristic of green economic policies geared towards sustainable development and poverty eradication..$^{41}$ In essence, it stated that SCP will lead to SD. The processes will relate to SP because that is how the world can sustainably 'develop', by 'producing' sustainably. The problem with this narrative is that it leaves SC (by itself) out of the picture by making no separate reference to it. and How Can the Law Interfere?

When does consumption become unsustainable and how do we define consumption and its sustainability? Further, what role does and should the law play in influencing our patterns and levels of consumption, if at all? Since the Earth Summit in 1992, when SC became synonymous with SCP, existing definitions under international processes started to define SCP as one concept. The UNCSD, at its second session, mandated the Oslo Ministerial Roundtable (hosted by the Norwegian Ministry of Environment and attended by governments, intergovernmental organisations, NGOS, business, trade unions and the academic community) to prepare elements for an international work programme

39 World Summit on Sustainable Development (WSSD), Johannesburg Summit 2002, <https://sustainabledevelopment.un.org/milesstones/wssd>, accessed 24 May 2018.

40 Plan of Implementation of the World Summit on Sustainable Development <http://www .un.org/esa/sustdev/documents/WSSD_POI_PD/English/WSSD_PlanImpl.pdf> para 14, accessed 24 May 2018.

41 UN General Assembly resolution 66/288, 'The Future We Want' (11 September 2012) A/ RES/66/288. 
on SCP. ${ }^{42}$ Accordingly, the Oslo Roundtable on Sustainable Production and Consumption defined SCP as,

the use of goods and services that respond to basic needs and bring a better quality of life, while minimising the use of natural resources, toxic materials and emissions of waste and pollutants over the life cycle, so as not to jeopardise the needs of future generations. ${ }^{43}$

This definition has been influential in formulating the SDGs. In adopting the 2030 Agenda for Sustainable Development the Members of the United Nations committed:

... to making fundamental changes in the way that our societies produce and consume goods and services. Governments, international organizations, the business sector and other non-state actors and individuals must contribute to changing unsustainable consumption and production patterns, including through the mobilization, from all sources, of financial and technical assistance to strengthen developing countries' scientific, technological and innovative capacities to move towards more sustainable patterns of consumption and production. We encourage the implementation of the 10-Year Framework of Programmes on Sustainable Consumption and Production. All countries take action, with developed countries taking the lead, taking into account the development and capabilities of developing countries. ${ }^{44}$

Further, the Oslo Roundtable report in its preface stated that the experts on the roundtable were focusing their analysis on the need for the developed world 'to put its own house in order' so far as consumption was concerned..$^{45}$ The report went on to clarify that the concerns of the developing world were taken into account so that the transition to sustainable patterns of consumption in the industrialized countries contributed to, but did not substitute the SD needs of other parts of the world. ${ }^{46}$ In doing so, the Oslo Roundtable's analysis

\footnotetext{
42 'Elements for an International Work Programme on Sustainable Production and Consumption' <http://enb.iisd.org/consume/oslooo1.html> accessed 7 January 2018.

43 Oslo Roundtable on Sustainable Production and Consumption (IISD), <http://www.iisd .ca/consume/oslooo4.html> accessed 26 February 2017.

44 'Transforming our world: the 2030 Agenda for Sustainable Development' (n 24) para. 28.

45 Preface to the Oslo Roundtable on Sustainable Production and Consumption $<$ http://enb .iisd.org/consume/oslooo2.html> accessed 8 January 2018.

46 Ibid.
} 
shared the responsibility for implementing SCP more or less equally between the developed and the developing world, something that the SDGs do not do as clearly or robustly.

Under the SDGs, the geographical burden of implementation of SCP-based programmes have fallen almost entirely on developing countries. Even though consumption patterns in countries of the Global North are still the highest in the world, the current SCP plan executed through Goal 12 of the SDGs looks at hazardous waste management and promotion of SP, while the manner in which we can define, address and regulate consumption itself remains unclear. The act of consuming and the regulation of consumer behaviour remained unaddressed because it is understandably difficult to regulate societal norms such as lifestyle, equity and cultural identity; these cannot be easily adjudicated in courtrooms or legislatures, ${ }^{47}$ in terms of consumer sovereignty and the freedom to consume as much in whichever way the consumer deems fit based on her cultural, social and economic reality. However, there is an urgent need to identify ways to regulate unsustainable consumption patterns.

Apart from James SALZMAN, who wrote on the relation between SC and the law in $1997,{ }^{48}$ there has been no substantial legal academic engagement with the topic, at least in the English-speaking world. Sustainable or 'conscious' consumerism are subjects dealt with largely within sociology, anthropology and to an extent, under economic theory for changing current patterns of consumption. Yet, important legal questions regarding the role of the law in promoting, or at least in avoiding any hindrance to SC could be extremely meaningful.

At the outset, it must be acknowledged that addressing SC is a difficult task, since it involves questioning fundamental assumptions about the way modern societies function. Intervening in consumer behaviour contradicts the muchvaunted idea of 'consumer sovereignty', as promoting the reduction of consumption would threaten a variety of vested interests and undermine the key structural role that consumption plays in economic growth. ${ }^{49}$ Daunting as the task may be, it must be addressed in light of the fact that developing countries

47 SALZMAN (n 10) 1256 .

48 SALZMAN (n 10).

49 Tim JACKSON, 'Sustainable Consumption' in G ATKINSON, S DIETZ and E NEUMAYER (eds), Handbook of Sustainable Development 2nd ed (Edwards Elgar 2014). 
are fast following the Western path of over-consumption of material goods. A new global middle class of urban consumers is adopting, at an alarming pace, the diet, transportation systems and lifestyles that were once mostly limited to the Global North. ${ }^{50}$ Added to this is the inherent problem of governments being hesitant to curb consumption since economic growth is defined by itconsumption increases the tax base, at the very least. Therefore, defining SC within a coherent legal framework becomes a formidable task.

Sociologists have criticized ideas within positivist legal frameworks that attempt to regulate SC by calling them inadequate, in the light of the social and cultural processes which affect consumption patterns. ${ }^{51}$ Care must be taken so as to not shift the entire responsibility of regulating consumption only onto the consumer, since individual choices are in fact, macro processes at work, because consumer behaviour is the outcome of local as well as global linkages of social interdependencies. ${ }^{52}$

Addressing SC requires two basic developments. Firstly, it calls for an increased efficiency of consumption, including via technological improvements (eco-efficiency) - that is, using production resources more sustainably. ${ }^{53}$ Some efforts have been made in this respect, for instance through international programmes promoting clean energy and energy efficiency. Secondly and overall, the concept of SC suggests changes in consumption patterns and reductions in consumption levels in industrialized countries and, then, in the developing world. ${ }^{54}$ National and international efforts in this regard are most often neglected. ${ }^{55}$

5o Sylvia LOREK and Philip VERGRAGT, 'Sustainable consumption as a systemic challenge: inter-and transdisciplinary research and research questions' in L REISCH and J THOGERSEN (eds), Handbook of Research on Sustainable Consumption (Edward Elgar 2015) 19, 19.

51 Paddy DOLAN, 'Sustainability of "Sustainable Consumption"' (2002) 22(2) Journal of Macromarketing 170, 172.

52 Ibid 172-173.

53 World Business Council for Sustainable Development defines eco-efficiency as 'Ecoefficiency is achieved by the delivery of competitively-priced goods and services that satisfy human needs and bring quality of life, while progressively reducing ecological impacts and resource intensity throughout the life-cycle to a level at least in line with the Earth's estimated carrying capacity.'

54 Doris FUCHS and Sylvia LOREK, 'Sustainable Consumption and Governance: A History of Promises and Failures' (2005) 28(3) Journal of Consumer Policy 261, 262.

55 Ibid $267-70$; FUCHS and LOREK acknowledge UnEP's plans and activities towards changing consumption patterns and reducing consumption levels as broad and promising, but also say that 'UNEP has yet to demonstrate its willingness and ability to move beyond its former explicit exclusion of the strong sustainable consumption perspective' (at 269). The authors further observe that while the Commission on Sustainable Development, 
This point can be illustrated by taking into account the current 10-year framework programme on the implementation of Goal 12 of the SDGs. The objectives of the programme are to improve resource efficiency, to decouple economic growth from resource use, to mainstream SCP into SD, to support capacity-building, access to finance and technology as well as information and knowledge-sharing. ${ }^{56}$ It can also be noted that the Johannesburg Plan of Implementation (which may be read together with the $10 \mathrm{YFP}$ ) recommends the application of the polluter-pays principle in framing policies and measures addressing SCP. ${ }^{57}$ While the polluter-pays principle could be applied to SP models, wherein economic responsibility for resource-intensive goods could be passed on to the producer or the consumer, it is unclear how the polluterpays principle could work for problems of hyper-consumerism as a result of affluence and lifestyle. The Plan also lays emphasis on public awareness and education, and endorses the development of consumer information tools to provide information regarding SCP, including human health and safety. It requires governments, international organizations and non-government organizations, including companies, to participate actively in encouraging SCP practices without really elucidating what these practices entail. An example of the vagueness of the Plan is its insistence on enhancement of corporate social and environmental responsibility. How would this 'responsibility' be defined and implemented? How would it help consumers make better choices in their lifestyles? Why would it make business sense for corporates to curb an activity which benefits them? It is also important to note that the Johannesburg Plan specifically omits SC when elaborating upon measures to be taken towards establishment of legal, financial and regulatory frameworks, which are the real tools for implementation. These remain restricted to sustainable production and eco-efficiency. 58

All these objectives pertain to SP and/or increasing efficiency of consumption and mainly look at developing countries and their ability to enhance

Division for Sustainable Development and oECD were initially ambitious about the above mandate in the late 1990s, the enthusiasm towards the same fizzled out due to its omission from the governance goals of the organizations.

56 See UN Enviornment Programme, 'What is 10YFP?' (nd) <http://web.unep.org/10yfp/ about/what-1oyfp $>$ accessed 4 March 2017.

57 United Nations, 'Johannesburg Plan of Implementation' (2002) $7<$ http://www.un.org/ esa/sustdev/documents/WSSD_POI_PD/English/WSSD_PlanImpl.pdf > accessed 4 April 2017.

$5^{8}$ See Plan of Implementation of the World Summit on Sustainable Development, section III point $16<$ http://www.un-documents.net/jburgpln.htm> accessed 9 January 2018. 
eco-efficiency of products. This imbalance between SC and SP is odd, because policies focused on consumption of products should be stronger than policies focused on their production if overall sustainability is to be achieved. ${ }^{59}$ Also, none of the programme objectives look at the dominant social paradigm or regulation of consumer behaviour, particularly in industrialised countries where per capita consumption is very high and, therefore unsustainable, notwithstanding their low population density.

It has been suggested that social trends are a hindrance to a reduction of consumption levels since they prevail, not necessarily because they are actively supported by a majority of the members of a society, but because they are held by dominant actors and groups, often as a way to legitimize existing institutions. ${ }^{60}$ The role of business, the consumer goods industry and their linkages with governmental institutions shed light on why regulating consumer behaviour has not attracted the focus it deserves in sustainability discourse. Regulating consumer behaviour to encourage SC has to be looked at both from macro-marketing, which would include regulating technology (ecoefficiency), economics and politics, as well as micro-economics (which focuses on individual decisions of firms and individuals).

Existing definitions of SC range from SC being a part of SD, as articulated by the Oslo Roundtable (which is perhaps the prevailing view), to SC being an umbrella term that brings together a number of key issues, such as meeting needs, enhancing quality of life, improving efficiency, minimising waste, taking a life cycle perspective and taking into account the equity dimension. ${ }^{61}$ The International Institute for Environment and Development suggests that ' $[t]$ he special focus of sustainable consumption is on the economic activity of choosing, using, and disposing of goods and services and how this can be changed to bring social and environmental benefit. ${ }^{\prime} 2$

This definition, without providing a narrow understanding of what SC is or should be, focuses instead on what aspect of SC needs to be regulated-i.e. the economic activity of a consumer when he or she makes a choice, uses and

59 SALZMAN (n 10) 1255 .

6o William E KILBOURNE, 'Consumption Ideology and the Dominant Social Paradigm in the UK: Is Demarketing Consumption a Necessity?' (Globalisation and Equity Conference 2001).

$61 \quad$ JACKSON (n 49) 281.

62 Ibid. 
disposes particular goods and services. Further, it does not attempt to combine SC with SP, which Transforming our World ${ }^{63}$ and Goal $12^{64}$ of the SDGs try to do.

In contrast to SP's clear goal of reducing pollution and moving towards clean energy, SC has no ultimate objective, blurred even further by politics and disagreements between the North and the South. ${ }^{65}$ Current debates over SP focus on the best means to reduce pollution further-how can we make laws more efficient and effective through risk analysis and economic analysis? On the other hand, as far as SC is concerned, the international community has neither a common understanding of the problem, nor of the solution. It is therefore imperative that first and foremost, SC and SP be decoupled (instead of the blanket SCP) to start discussing how international and national laws can support SC programmes that correctly reflect and address the environmental and social costs of a product, so that consumers are encouraged to make better consumption choices.

\section{5}

\section{Regulating Sustainable Consumption through the Legal Principles}

A society's cumulative burden on the environmental ecosystem is a function not only of its population size and modes of production, but also its consumption levels and technology base. ${ }^{66}$ As far as the law is concerned, one needs to understand what the legal treatment of consumption should be by asking, for example, what a supermarket would look like in a more sustainably consuming society?67 The rhetoric of 'consumer sovereignty' and 'hands-off' governance is unhelpful in figuring out how laws may be used to regulate SC because it regards consumer choices as purely individualistic. Therefore, sustainable consumption requires a more sophisticated policy approach aimed at identifying and addressing perverse incentive structures. ${ }^{6}$

It may be surmised that a regulatory regime may be workable through a mix of both carrot and stick measures. LOREK and VERGRAGT suggest that the 'stick' be strong government regulations, which may for instance involve a

63 See 'Transforming our world: the 2030 Agenda for Sustainable Development' (n 24) para. 28.

64 Ibid Goal 12 and its Targets.

65 SALZMAN (n 10) 1254-1255.

66 Ibid 1252.

67 Ibid 1257 .

68 JACKSON (n 49) 262. 
capping of unsustainable consumption levels. The 'carrot' for strong sustainable consumption, on the other hand, could be to raise the awareness of the fact that a 'slimming' of the economy, that is, reducing its physical throughput, would lead to substantial positive outcomes-if we are prepared for it. ${ }^{69}$

The following builds on this and suggests a combination of 'carrots' and 'sticks' involving direct regulation, economic incentives and the application of some existing principles of international law. The aim is not to provide a definitive policy agenda, but rather to provide a preliminary examination on some possible measures which could help to promote SC.

\subsection{Public-Participation and Access to Information}

Law can regulate consumption by making a consumer aware of a product's ecological footprint, including that of its manufacturing and disposal costs, so that, eventually, unsustainable products are eased out of the system. This could be done through a regulation requiring labels containing such information. Alternatively, a system of economic incentives could help raise consumers' awareness and, in a sense, internalize some of the externalities of consumption..$^{70}$

While there are many diverging views about the manner and role that consumers can play in SC, there is a substantial body of literature that, to some degree, is agreeable to the view that choices made by consumers based on their social and environmental conscience positively affect overall consumption patterns. PAAVLOVA points out that wide-scale collective action amongst consumers will lead to environmentally desirable outcomes, ${ }^{71}$ to which the law can positively contribute. SUNSTEIN believes that consumers often make

69 LOREK and VERGRAGT (n 50) 28.

70 Richard STEWART advocates greater use of economic incentives systems including taxes on pollution, rather than command and control measures that currently dominate environmental regulation. Either way, indirect measures through economic instruments have been advocated as efficient policy tools to regulate environmental degradation. The same tools may also be stretched to include sustainable consumption objectives. See Richard STEWART, 'Introduction: Environmental Regulation in Multi-Jurisdictional Regimes' in RL REVESZ, P SANDS and R STEWART (eds), Environmental Law, the Economy and Sustainable Development: The United States, the European Union and the International Community (CUP 2010) 19 .

71 Jouni PAAVLOVA, 'Towards Sustainable Consumption: Economics and Ethical Concerns for the Environment in Consumer Choices' (2001) 59(2) Review of Social Economy 227, 247 . 
choices that hurt their future selves due to factors he refers to as 'internalities. ${ }^{72}$ According to him, these 'internalities' result in 'intra-personal collective action' problems. Therefore, Sunstein's view draws the linkage between 'individual consumer choices' with 'collective consumer action.' Applying this hypothesis, we cannot see individual consumer choices as completely irrelevant to promoting overall sustainable consumption practices. Taking from available empirical and epistemological literature, it can be assumed that there is a nexus between consumer choices, both individual and collective, and the sustainability of consumption practices, and that is what makes regulating consumer behaviour important in the sustainability discourse. UNEP's Division of Technology, Industry, and Economics and the OECD have also acknowledged these linkages in their works on sustainable consumption. ${ }^{73}$

The first step towards positive action by consumers is the availability of information. Currently, a consumer is largely unaware of the choices he or she makes. There is neither a legal necessity for the producer of a product to divulge the information regarding a product's lifecycle, nor do the prices reflect a product's social and environmental cost. While there are labelling requirements for specific industries in most jurisdictions, this problem has not been paid due attention from an international law perspective. This is the reason why many can purchase a T-shirt from a resource that is harvested, sown, sewn and transported for a price less than what one might pay for a sandwich and never even question the transaction. The consumer is often unaware of the real cost that the production of the T-shirt imposes on societies and the environment.

The legal basis for providing information to the consumer is a wellestablished procedural principle of international environmental law in the form of public participation and access to information. ${ }^{74}$ Principle 5 of the New Delhi Principles states that public participation and access to information are reflected as two sides of the same coin. ${ }^{75}$ Public participation can also

72 Cass SUNSTEIN, 'Behavioral Economics, Consumption and Environmental Protection' in L REISCH and J THOGERSEN (eds), Handbook of Research on Sustainable Consumption (Edward Elgar 2013) 313, 313.

73 LOREK and VERGRAGT ( n $_{50}$ ).

74 See Rio Declaration on Environment and Development (n 29) Principle 10.

75 The UN Commission for Sustainable Development and other bodies, the ILA Committee on the Legal Aspects of Sustainable Development elaborated a set of 'Principles of International Law for Sustainable Development', which are meant to 'support the balanced integration of laws and policies at the intersection of international environmental, social and economic law.' The said set of principles, The New Delhi Declaration of Principles of International Law relating to sustainable development espouses 7 principles 'The Principles of International Law Related to Sustainable Development'. One 
be defined as an 'instrument of deliberative democratic systems that seeks to capture the concerns and opinions of the people affected by government's decisions, or of the citizenry in general. ${ }^{76}$ Consumers represent the 'demand' side of the process of consumption. Consumer choices are therefore also drivers in the nature of overall consumption patterns globally. Without infringing upon 'consumer sovereignty, the task of development of SC patterns will certainly become easier with the support of consumers, if consumers are kept informed about making sustainable choices. ${ }^{77}$

It has been observed that consumers have an influence on policies through two arenas: the market and politics. ${ }^{78}$ As consumers play dual roles in affecting suitable legal and policy interventions through persisting choices, the market and politics around consumption can change. These interventions could include measures such as performance standards and mandatory labels, corporate sustainability reporting and engagement of different stakeholders, including consumers, through public participation as envisaged under the Aarhus Convention. ${ }^{79}$

Regulations requiring producers to adhere to certain performance standards or using labels signifying their product's environmental impact over its life cycle might be a matter of state intervention in promoting sustainable consumption. ${ }^{80}$ Such mandatory requirements would allow the consumers to make informed choices. Mandatory performance standards and labelling in relation to energy efficiency have resulted in environmentally desirable

of the principles is public participation and access to information. See ILA, New Delhi Declaration of Principles of International Law Relating to Sustainable Development (2 April 2002) <http://cisdl.org/tribunals/pdf/NewDelhiDeclaration.pdf > accessed 5 May 2018.

76 Rebeca MACIAS, 'Public Participation in Energy and Natural Resources Development: A Theory and Criteria for Evaluation' (Canadian Institute of Resources Law Occasional Paper 34, 2010).

77 FUCHS and LOREK (n 54) 278.

78 Working Party on National Environmental Policy, 'Participatory Decision-making for Sustainable Consumption' (oEcD Programme on Sustainable Consumption 2002) $<$ http://www.oecd.org/officialdocuments/publicdisplaydocumentpdf/?doclanguage=en \&cote=env/epoc/wpnep (2001)17/final $>$ accessed 9 January 2018.

79 Convention on Access to Information, Public Participation in Decision-Making and Access to Justice in Environmental Matters (25 June 1998) 2161 UNTS 447.

80 Choosing the regulatory instrument of preference, whether standards or labelling, is a topic that requires much more in-depth study. The main message is that the act of choosing a regulatory instrument could be a starting point in the promotion of sustainable consumption. 
outcomes in Australia, New Zealand and Mexico. ${ }^{81}$ The same may be extended to other areas of consumption, discussed under 'direct regulation' below.

Corporate sustainability reporting with information about product lifecycles could also be further encouraged or even become a legal requirement. Such reporting could oblige companies to inform consumers of their social and environmental values and practices beyond the sustainability characteristics of individual products. While the following is not prevalent yet, ${ }^{82}$ Corporate Sustainability Reports could be required to elaborate on the life cycle impact of a particular range of products by a company. The Global Reporting Initiative (GRI) was established in 1997 by a number of companies and organizations belonging to the 'Coalition for Environmentally Responsible Economies,' with the objective of developing globally applicable guidelines for reporting on economic, environmental and social performance, initially for corporations and eventually for any business or governmental or non-governmental organization that wants to be part of the GRI framework. ${ }^{83}$ While initiatives such as the GRI work on a limited, voluntary level, standards used therein could provide an international framework under an SC programme for ascertaining a company's 'sustainability' and then communicating the results to a consumer, which could be made mandatory under national laws under the auspices of an international treaty with an overarching framework calling for signatories to adopt sustainable consumption practices specifically. The treaty could also prescribe minimum global standards so that a company is prohibited from shifting its costs to an economy with lower reporting standards. Of course, this would be subject to negotiation and agreement between countries, but a jumpstart in this direction is required.

\subsection{Regulating Product Information}

Currently the prices of goods do not capture the main costs that make current consumption patterns unsustainable. For instance, they do not reflect the harm caused by emissions from shipping raw materials and finished products around the world, nor do they reflect the costs of disposing of the product. ${ }^{84}$ Likewise, prices typically do not reflect the harm caused by extractive industries on natural resources. Prices also fail to give any indication of the

\footnotetext{
81 OECD, 'Promoting Sustainable Consumption: Good Practices in oecD Countries' (oECD, 2008) <https://www.oecd.org/greengrowth/40317373.pdf> 9-11.

82 Ibid 33 .

83 Carl-Johan HEDBERG and Fredrik VON MALMBORG, "The Global Reporting Initiative and Corporate Sustainability Reporting in Swedish Companies' (2003) 10(3) Corporate Social Responsibility and Environmental Management 153, 155 .

84 SALZMAN (n 10) 1257.
} 
greenhouse gas emissions implied by the production of a good. Further, headto-head price competition in the marketplace is distorted because it is artificially biased towards environmental externalities, with the overall result of the consumer being completely unaware of the hidden costs and impacts of his or her purchase. ${ }^{85}$ The law can address this by making it compulsory to divulge information about a product's life cycle. Even though price control or information will not directly control consumption, an informed consumer might exercise his or her judgment to make ecologically sound decisions. International coordination could be helpful in ensuring that information is transmitted from jurisdiction to jurisdiction, using equivalent methodologies, in order to create consistent information on the global footprint of a product.

Consumption policies may include warning labels on more kinds of goods than, for example, the harm caused by cigarettes-such as warning the consumer about the high resource use behind a product. Such warning labels may be made mandatory through explicit regulations. There could be a direct ban on advertising obviously harmful products and limits could be set on wayside billboards by taxing advertising based on its resource consumption. ${ }^{86}$ Sweden, Norway and Quebec have bans on direct advertising targeting children under the age of 12 . This could also be discussed as a possible way forward not only by protecting children from consumerism but also towards bringing the next generation under SC practices and making them aware of the impact of individual choices on our planet - for instance for non-electric cars or meat products.

Brazil's law on $\mathrm{SC}^{87}$ is an interesting example of how direct regulation may work in addressing consumption. Drafted in 2015, the law has listed 19 objectives, including for instance the re-use of and recycling of packaging and products; encouraging companies to incorporate social, cultural and environmental dimensions in their production and management processes; and ensuring the right to information and promotion of environmental labelling. To achieve these objectives, federal, state and municipal governments are called on to carry out public awareness campaigns and train teachers on including sustainable consumption in the curriculum.

\footnotetext{
85 Ibid 1258.

86 Christer SANNE, 'Willing Consumers-or Locked-in? Policies for a Sustainable Consumption' (2002) 42(1-2) Ecological Economics 273, 284.

87 Law 13.186 on the Policy for Education on Sustainable Consumption (Política de Educação para o Consumo Sustentável) <http://www.lse.ac.uk/GranthamInstitute/law/ law-13-186-on-the-policy-for-education-on-sustainable-consumption/> accessed 3 April 2017.
} 


\subsection{Price-Signals and Taxes}

Prices could also disincentivize the consumption of goods that have a particularly high impact on the environment. Chapter IV of Agenda 21 states that, without the stimulus of prices and market signals, significant changes in consumption and production patterns seem unlikely to occur in the near future. ${ }^{88}$ In broad terms, this could involve policies extending the responsibility of producers, for instance by charging producers with the duty to take back their products after use in order to reduce the volume of waste, and encourage recycling and development of lean products. ${ }^{89}$

Consumption remains an area closely linked with 'neo-marketing' — a colloquial term used for new-age marketing that aims at selling lifestyles and social imaging. Today's marketing merits renewed examination because apart from the fact that current consumption patterns are ecologically unsustainable, marketing is steadily becoming more intrusive as it takes a firm grip of media and enters public institutions. Since the 1990s, large multinationals have developed their brands into lifestyle concepts. Firms like Nike, Coca-Cola and McDonalds turn from marketing goods or services to developing their brands into dominating signals of a 'feel good lifestyle' (Klein, 2000). ${ }^{90}$ Marketing signals such as these require new and innovative economics to address postconsumerist culture.

Incentivizing the development of the repair industry is another forgotten area which needs critical revival and is extremely relevant in the sustainability discourse. Currently, it is too often cheaper to throw out and buy something new rather than repair the old. Sweden has been trying to address this problem by looking at tax breaks on repairs of everything from bicycles to washing machines so that it will no longer make sense to throw out old or broken items and buy new ones. ${ }^{91}$ Regulations could alternatively require producers to keep separate parts for maintenance over the extended life of a product, and to make these parts available at a reasonable price.

88 Agenda 21 (n 11) Chapter IV.

89 SANNE (n 86) 284 .

90 Ibid 279. See also, Naomi KLEIN, No Logo: Taking Aim at the Brand Bullies (Knopf Canada 2000).

91 Richard ORANGE, 'Waste Not, Want Not: Sweden to Give Tax Breaks for Repairs' The Guardian (19 September 2016). 
SD has acquired the status of the most significant and influential legal and policy-making principle in all areas of activity, in particular as an indispensable tool in managing development law. ${ }^{92}$ Modern environmental laws concentrate on pollution control. As a result, factories are becoming cleaner and more efficient. However, the significance of resource efficiency and clean tech is diminished by the fact that we are continuing to consume more, which is still accelerating the use of natural resources, both in developed and developing countries. ${ }^{93}$ While SD looks at refining modes of production to reduce pollution, sustainable consumption should also be promoted in order to regulate the quantity and quality of consumption

The need to promote SC becomes especially relevant in a context where a sharp rise of affluence in transition and new economies equate development and welfare with consumption. However, the international legal community has not looked at governing consumption in the way it has looked at $\mathrm{SD}$, which is why even though there are far more national and international environmental laws existing today than 50 years ago, overall planetary health is in much worse shape. This problem is further exacerbated because sustainable consumption, the few times it is mentioned, is coupled with sustainable production which is targeting the mode of production without addressing why we are producing. Environmental protection policy has been almost exclusively concerned with what is an acceptable level of pollution and what kind of legal rules would be best suited for reducing pollution to that level. Sustainable consumption, on the other hand, has been the forgotten child of collective thought perhaps because it questions more fundamentally the way of life of the well-to-do classes. ${ }^{94}$ Promoting sustainable consumption almost inevitably conflicts with the notion of consumer sovereignty and even, possibly, with individual rights and freedoms. ${ }^{95}$ Ways to balance sustainable consumption with these rights and freedoms need to be found by carefully reviewing numbers of potential regulatory tools of relevance.

To put the essence of this article in a few words, it is proposed that we 'decouple, define and regulate SC using appropriate legislation (depending on a

\footnotetext{
92 Malgosia FITZMAURICE, 'The Principle of Sustainable Development in International Development Law' in AF Munir MANIRUZZAMAN (ed), International Sustainable Development Law (UNESCO 2010) 112.

93 SALZMAN (n 10) 1244-1245.

94 Ibid at 1253.

95 SANNE (n 86) 282.
} 
country's social and economic realities) and price-signals.' Current approaches to SC concentrate on production processes and consumer products, suggesting that the route to sustainable consumption lies mainly in the more efficient production of more sustainable products. Others seem to want, almost deliberately, to conflate these two issues. ${ }^{96}$ A good example of this can be seen in the speech made by a former UK Trade and Industry Secretary where she said:

there is nothing wrong with rising consumption, indeed it is to be welcomed as symptomatic of rising living standards in our communities. And it is quite right that the poorest in the world aspire to escape poverty and enjoy those standards. But we need to make sure the products and services we consume are designed not to harm our environment. We can enjoy more comfort, more enjoyment and more security without automatically increasing harmful and costly impacts on the environment. But it requires a re-thinking of business models to make more productive use of natural resources..$^{97}$

By addressing eco-efficiency and SP only, this narrative fails to look at what happens when there is a conflict of interest between consumption and sustainability. Which one do we pick? Evans and Jackson examine whether the concepts of sustainability and consumption itself are contradictory, making 'Sustainable Consumption' an oxymoron. ${ }^{98}$

Either way, the idea that we can safely keep consuming by adopting sustainable production standards is incorrect and often used by dominant groups with vested interests. There is also a need to expand our notions of development from primarily economic development, which is resource intensive. Development is also spiritual, intellectual and cultural, all of which can turn people away from excessive consumption. It is interesting to note that in developed countries, 'well-being' has for some time already been decoupled from economic growth. ${ }^{99}$

When SC is combined with SP, it gives one the sense of wanting to have their cake and eat it too: a normative decoupling is essential to the regulation of consumption. Currently, both national and international laws do not look at the overall cycle of the product. Products are regulated specifically and

$96 \quad$ JACKSON (n 49) 256.

97 Speech made by Patricia HEWITT in 2003, reproduced in Tim JACKSON (n 49) 257.

98 David EVANS and Tim JACKSON, 'Sustainable Consumption: Perspectives from Social and Cultural Theory' (Resolve Working Paper 05-08, nd) <http://resolve.sustainablelife styles.ac.uk/sites/default/files/RESOLVE_WP_05-08.pdf> accessed 1 April 2017. 
piecemeal, with the overall effect of shifting the environmental problem to another part of the lifecycle. This can be clearly seen when SC and SP are linked together - the overall responsibility (in terms of programmes and measures) of the sustainability narrative falls on the developing world, while the consumption patterns of developed countries continue unabated and without deliberation.

Once sustainable consumption and sustainable production are decoupled and SC is properly defined, policy-makers can attempt to effectively pursue the goals of sustainability. This can be done only when regulatory instruments are tailored to fit consumption instead of being universalised. Regulating consumption patterns through information, education and price signals is a positive step in the direction of revising policy to meet current needs, with the objective of achieving overall sustainability of global resources. 